\title{
The Development of Research-Based Learning Materials with Problem Solving and Problem Posing Oriented of Mathematics Statistics
}

\author{
Ika Krisdiana ${ }^{1}$, Titin Masfingatin ${ }^{2}$, Wasilatul Murtafiah ${ }^{3}$ \\ 1,2,3 Universitas PGRI Madiun \\ Correspondence Address; ikakrisdiana.mathedu@unipma.ac.id
}

\begin{abstract}
This study aims to describe the feasibility of research-based learning materials with problem solving and problem posing oriented of Mathematics Statistics. This research is a development research refers to the instructional development cycle by Fenrich (1997). Data collection techniques by observation, tests, and closed questionnaires. Data analysis techniques used qualitative and quantitative descriptive analysis (mixing method). The results: (1) a valid Semester Learning Plan (RPS) both in content and construct, Student Activity Sheet (LKM) based on research and a Learning Result Test (THB) assessment sheet with good and very good assessment from the validator that can be used with few revision, (2) positive response from students to teaching materials amounted to $88.67 \%$, (3) effectiveness of teaching materials was seen based on student learning completeness of $78.20 \%$ and better compared to classes that are not taught to use research-based learning teaching materials developed. The development of research-based learning materials with problem solving and problem posing oriented are valid, practic and effective that suitable for use in Statistics Mathematics learning process.
\end{abstract}

Keywords: Research Based Learning; Problem Solving; Problem Posing

\section{INTRODUCTION}

The learning must develop the student's active participation in building their knowledge. It will be realized if the learning can facilitate and provide sufficient space for the development of student activity. the Student activity can be cultivated among them by activities in the form of research . one of research that is involving research activities on the students is Research Based Learning (PBR). PBR is learning that starts from problems, extracts knowledge and skills, resolves problems or applications and ends with reflection, , the student can control and determine most activities (Prahmana, 2015).

In addition to problem solving activities, the students' thinking skills will develop with problem posing. problem posing is the task given to the student in the form of filing (making) problems (questions) (Akay \& Boz, 2010; Nuha, Waluya, \& Junaedi, 2018; Siswono, 2008). Learning to submit problems is effective towards understanding the students' mathematical concepts (Susanti, Sukestiyarno, \& Sugiharti, 2012). the applying of problem posing facilitates understanding of the concepts learned so as to provide better learning outcomes than conventional teaching. In addition, mathematics learning becomes more fun and positive effect (Kilic, 2013), namely students become more active in learning.

The problem that can be identified from mathematics statistics learning in the student of Mathematics Education Program at the University of PGRI Madiun is the low problem solving ability. Based on grade of final examination data (with the questions of Problem form) as many as $54 \%$ of students still do not meet the mastery of learning. its means that 
students do not yet have good problem solving skills on statistical questions in the problem forms. the question of problems form require active participation of students in learning and high-level thinking skills to be able to solve them. Based on the descriptions and problems, the researcher want to develop research-based teaching materials in the Mathematics Statistics course with orientation to problem solving and problem posing activities. Another reason is the lack of existence of innovative mathematical statistical teaching materials. So far the teaching materials used are only in the form of textbooks and material that are arranged by lecturers in power point as the learning resource for students.

The Based on previous research, several researchers have been conducted in developing teaching materials (Febriana, Sulur, \& Yudyanto, 2014; Herwati, 2016; Latifah, 2015; Mardayani, Hamdi, \& Murtiani, 2013; Mulyana, 2012; Putra \& Anggraini, 2016; FK Sari, Farida, \& Syazali, 2016; Siska, 2015; Sri Anggoro, 2015; Susialita, 2016; Wibowo \& Pratiwi, 2018) especially in developing statistical teaching materials (Fitri, 2011; Sari \& Surya, 2017). Learning that refers to PBR has also been widely developed (Blackmore \& Fraser, 2007; Chrysti S, 2012; Masfingatin, Murtafiah, \& Krisdiana, 2017; Slameto, 2015; Slameto, Wardani, \& Kristin, 2016). However, there are no researches that have developed Research-based learning materials with problem solving and problem posing oriented of Statistics Mathematics. So, the purpose of the research is to describe the feasibility of developing Research-based learning materials with problem solving and problem posing oriented of Statistics Mathematics.

\section{THE RESEARCH METHODS}

This research is the development research referring to the instructional development that is developed by Fenrich (1997) which consists of five phases, namely: (1) analysis phase , (2) planning phase (3) design phase, (4) develop phase, and (5) implementation phase. The subjects in this study were students who took Mathematics Statistics courses in the Mathematics Education Program at the University of Madiun PGRI Even Semester (6) 2017/2018 academic year.

The data collection technique is observation, tests and questionnaires. While the data analysis was carried out in qualitative and quantitative descriptive (mixed method) with research design using Experimental Embedded Model (Creswell, 2012; Sugiyono, 2015). Experimental Embedded Model Design is the research design that combines qualitative methods simultaneously with quantitative methods or vice versa (Sugiyono, 2015). In this research, the qualitative methods are used to analyze the students needs and lecturers and mathematics statistics learning, then quantitative methods are used in the development phase, namely in testing research-based learning devices, then the results of both data are represented qualitatively.

\section{THE RESULTS OF THE RESEARCH AND THE DISCUSSION}

This research was conducted at the Faculty of Education department (FKIP) the department of Mathematics Education Program at the University of PGRI Madiun Even Semester 2017/2018 Academic Year. The research subjects were 84 students who took 
Mathematics Statistics. The results of the research activities were described for each stage of the development of learning devices referring to the Fenrich (1997) development model which consists of five phases, namely: (1) analysis phase , (2) planning phase, (3) design phase , (4) develop phase, and (5) implementation phase.

\section{Analysis Phase}

The activities carried out in the analysis phase are identifying and developing the understanding of the students needs analysis and lecturers in the Mathematics Statistics course. This activity is carried out by observing the learning design and teaching materials used and the assessment instruments for Mathematics Statistics. The stages of needs analysis include two stages, namely curriculum analysis and analysis of learning resources. The results of curriculum analysis have been carried out as follows: (1) Achievement of Subject Learning: the student understand and apply mathematical theoretical concepts which include opportunity theory and statistics, (2) appropriate learning methods are Problem solving and problems posing based on the data students that are lack mastery of questions statistics in the problem form. In addition to curriculum analysis, analysis of learning resources was also conducted. The results of the analysis of learning sources are data from the identification of the needs of teaching materials Mathematical Statistics that match the characteristics of students and material characteristics.

Based on the analysis that has been carried out on learning Mathematics Statistics, the students have difficulty in solving problems in the problems form. the students are not familiar with the problems in the problems form so they can determine the solution to the problem presented. On the other hand, the learning resources used are only text and power point books compiled by lecturer lecturers. This is not yet felt or can facilitate the Increasing and development of problem solving abilities.

\section{Planning phase}

The activities carried out on the planning phase are determined by the research implementation team and determine the research instruments (validation sheets, observation sheets for the implementation of student learning and activities). The research starts from the analysis phase to the implementation of learning devices. Before the implementation phase of the learning device the team designed and developed PBR-oriented learning devices. The development activities include the process of validating the feasibility of learning devices by material experts, experts in media and learning design by lecturers at the FKIP University of PGRI Madiun who have at least doctoral degrees and have academic positions as lecturers lector. After being declared valid then the implementation phase, which is implementing teaching materials in the learning process.

\section{Design Phase}

The design stage in this research includes the designing of Semester Learning Plans (RPS), Student sheets activity (LKM), and assessment sheets.

\section{a. the designing of Semester lesson Plans (RPS)}

Research-based RPS contains information on courses, learning outcomes of study program graduates, learning achievement stages, material, learning methods, time allocation, assessment and reference list used (Kemenristek Dikti, 2016). RPS is prepared by referring 
to PBR characteristics, namely by inserting activities research on some material in the Mathematics Statistics course. The learning method used is problems solving and problems posing. The selection of this method on the basis of students' problem solving skills will be better because the students are faced with the problems.

b. Student sheet activity (LKM)

LKM that are prepared prioritize research activities / activities and follow the steps in research-based learning. LKM are designed according to the steps in the research-based learning process that starts from the delivery of the results of previous research related to the material being studied (Slameto et al., 2016). Furthermore, the lecturer presents authentic problems related to the material to be discussed in the research group. The lecturer tries to make the connection between student experience or knowledge become more contextual, that is by making students experience or knowledge directly (contextualization) (Abduh, 2018). This aims to make learning more meaningful for students. In addition, students can also conduct investigative activities. The research-based learning in the learning process is the implementation of the combination of the characteristics of research actions and meaningful learning (Slameto et al., 2016). The problems presented at the LKM require the student to conduct investigations while determining their resolution. The design of the LKM designed in this study is as follows.
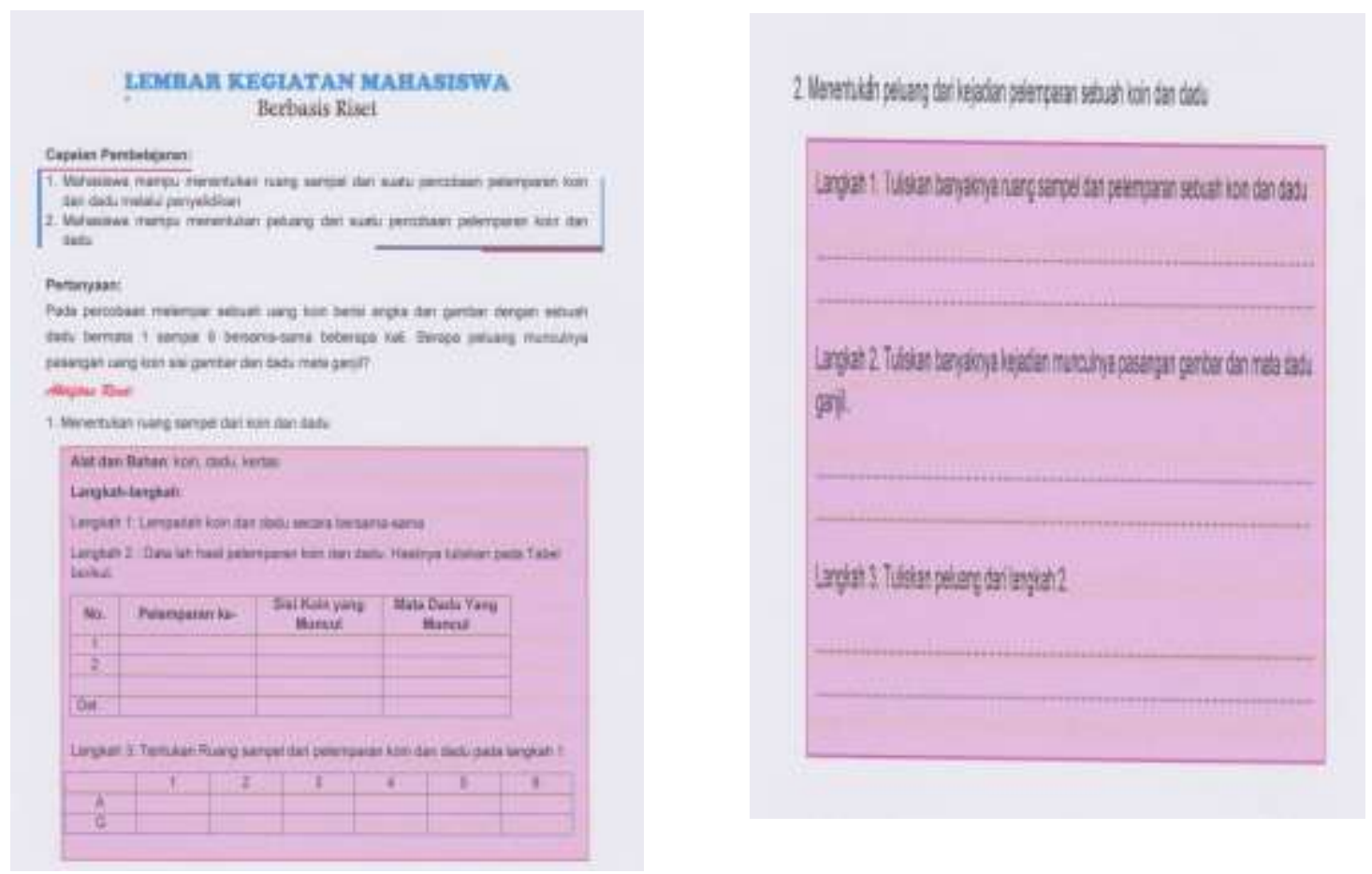

Figure 1. Research Activities in Research-Based LKM

The research activities facilitate students to collect the information through experimental activities. The questions that arise are used as a foundation for the students in collecting more information from available sources, students can also conduct experiments or research to answer questions that arise in the students (Abduh, 2018). The students collect the data 
and conduct investigations related to the problem then concludes the results of the investigation.After the students do research and deliver results in class presentations, the next is problem solving activities. In this activity students are faced with several problems related to research activities that have been carried out before. Examples of problem solving activities are presented in Figure 2

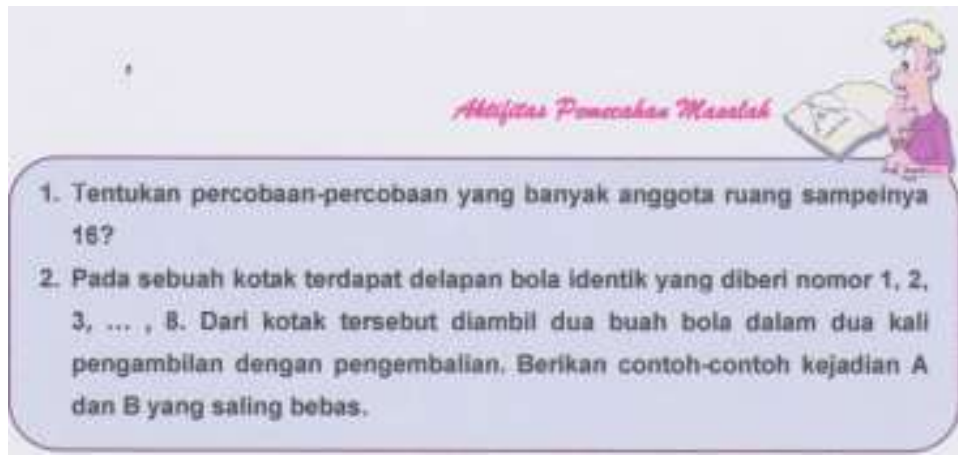

Figure 2. Problem Solving Activities

After the problem solving activities the next step is the problem posing activity. Posing of the problem is a task that asks students to submit or make new problems (questions) after completing the initial problem given (Siswono, 2008). Examples of problem posing activities are presented in Figure 3. below.

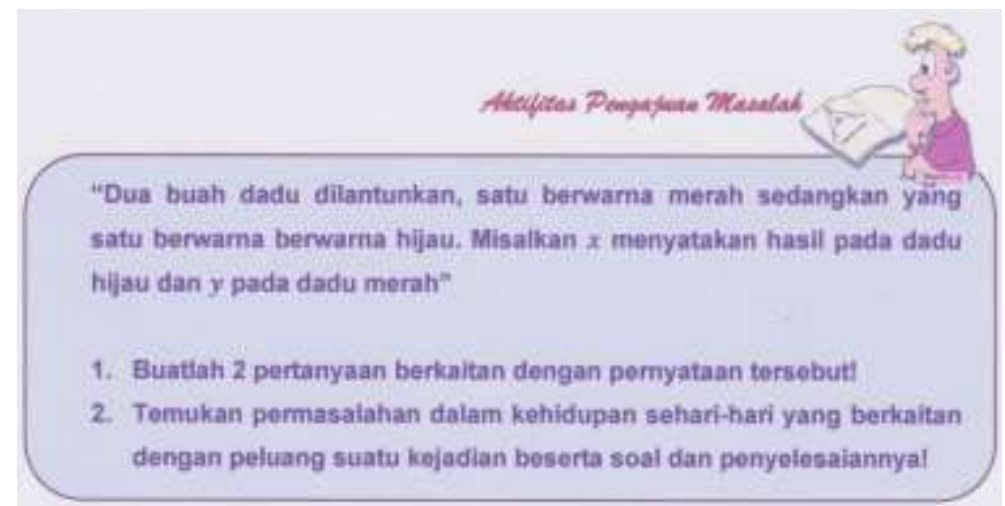

Figure3. Problem Posing Activity

\section{c. Assessment sheets}

The assessment sheets in the form of Learning Outcomes Test Questions (THB) are used to determine students' ability to solve and pose the problems. The THB problem consists of 4 questions in the essay form. Two questions in the problem solving form and two questions about problem posing form.

\section{Development Phase}

The activities carried out in this development phase are the study and assessment of the feasibility of learning devices which include RPS, LKM, and THB by the validator. The instrument used was the closed questionnaire containing an assessment of the content and construction of the RPS. The validator was the lecturer in the Mathematics Education 
department Program of FKIP University of PGRI Madiun who holds a doctorate in mathematics education and has experience teaching statistical subjects. The validation results that have been carried out by the validator are as follows.

\section{The Validation results of Semester Lesson Plan (RPS)}

The results of validation or assessment by three validators on the Semester Lesson Plan (RPS) that have been developed by the researchers team presented as follows.

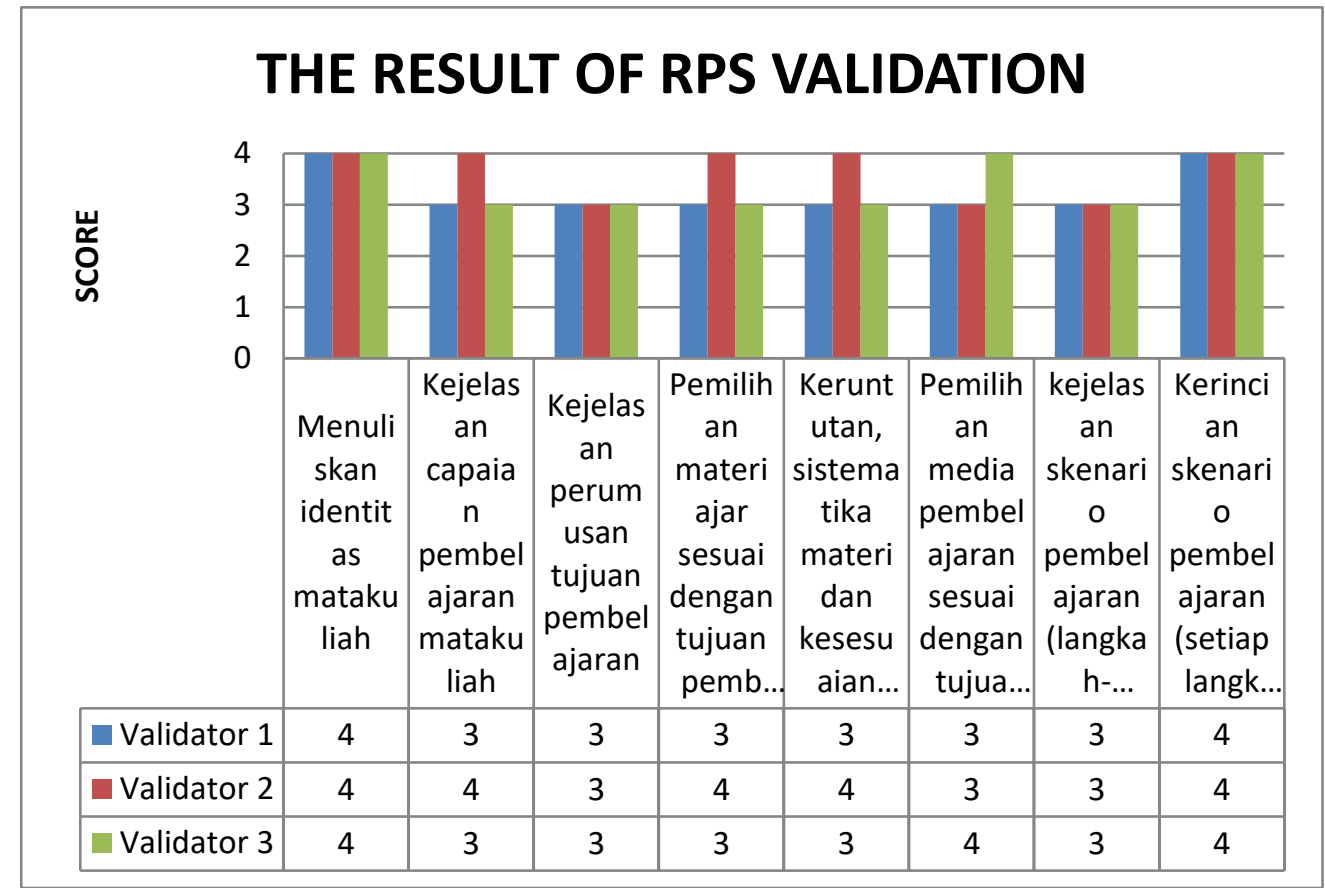

Figure 4. The result of RPS Validation

\section{Description:}
1 : it's mean "Not very good"
3 : it's mean "good"
2 : it's mean "Not good"
4 : it's mean "very good"

Based on Figure 4, it shows that all three validators provide assessments 3 and 4 for each indicator of assessment of RPS. This shows that the components in the RPS get good and very good ratings. Conclusions based on the results of validation are RPS that have been developed by valid research teams used in learning.

The assessment carried out on Research-based RPS includes content assessment and construct assessment. Content assessment includes assessment of the clarity of the formulation of learning outcomes, formulation of achievement indicators, selection of teaching materials, selection of learning media, and clarity and detail of learning scenarios. The assessment of the construction of the RPS includes an assessment of the writing of the RPS identity as well as the suitability and systematic learning.

\section{The Validation Result of The student sheet Activity (LKM)}

The assessment results of the three research-based LKM that have been developed are presented in Figure 5. below. 


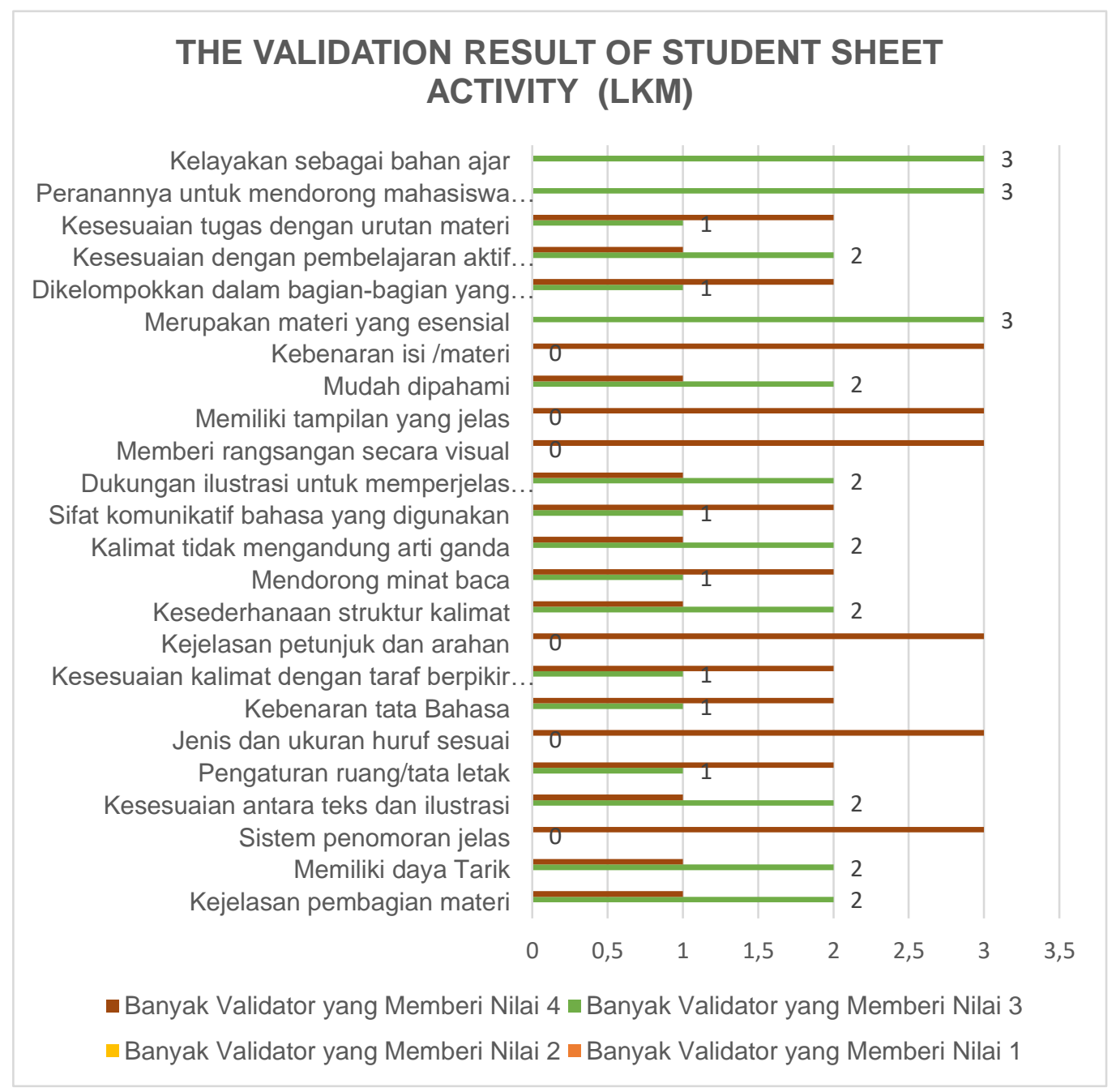

Figure 5. The Validation Research of LKM

\section{Description:}
1 : It means "Not Very Good"
3 : It means "Good"
2 : It means "Not Good"
4 : It means "Very good"

Based on Figure 5, it shows that in each aspect of the assessment of the three validators gave assessments 3 and 4. This indicated that the material in the LKM had good and very good ratings. The validator also gives advice / input to the draft 1 LKM. Revisions based on suggestions / input from the validators were carried out in some materials that was not in accordance with research-based learning. So it can be concluded that Research-based LKM with problem solving and and problem posing can be used with a few revision.

\section{The Results Validation of Learning Outcomes Test}

The results of the assessment by three validators (lecturers of the Mathematics Education department Program of FKIP at University of PGRI Madiun) on the test of learning outcomes that have been developed by researchers are described in Figure 6. below. 


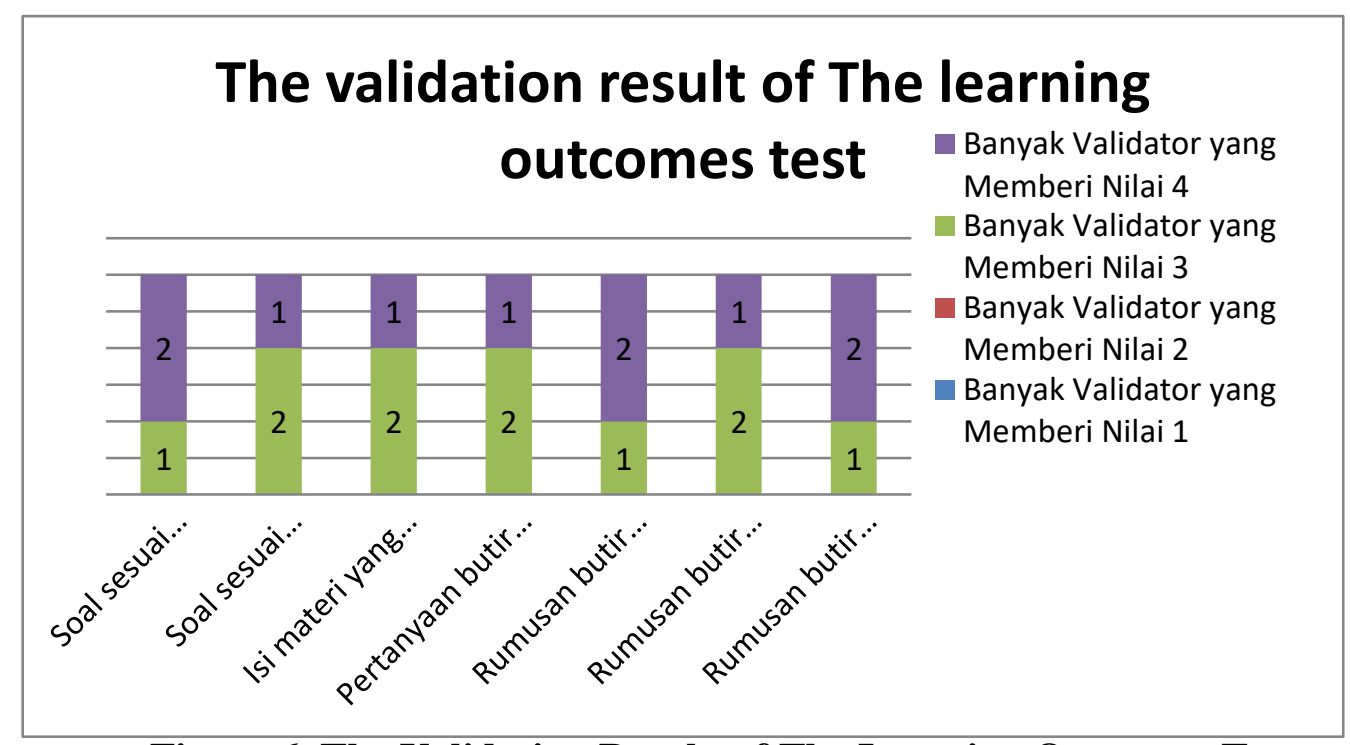

Figure 6. The Validation Result of The Learning Outcomes Tes

Based on Figure 6, it shows that all three validators gave assessments 3 and 4 on the Learning Outcomes Test (THB) problem. This shows that the components in the THB assessment sheet get good and very good ratings. The validator also gave a little few advice and input to the draft 1 THB that had been designed by the research team. Thus the valid THB assessment sheet and can be used but with a few revisions.

\section{Implementation Phase}

The activities were carried out at the implementation stage were the application of instructional materials oriented to solving and posing problems by referring to the steps of research-based learning in the Mathematics Statistics course. In the implementation phase, learning devices that have been developed in the develop phase are applied in the trial class. The results obtained at the implementation stage were as follows.

a. Solving and posing problems ability

The students' ability to solve and pose the problems is known through the results of test methods using THB instruments that have been validated by the validator. The tests are given to students after the application of the research-based learning. The description of the achievement of problem solving and posing abilities from 25 students (class 6C) is reflected in the value of the learning outcomes test which can be seen in Figure 7. below. 


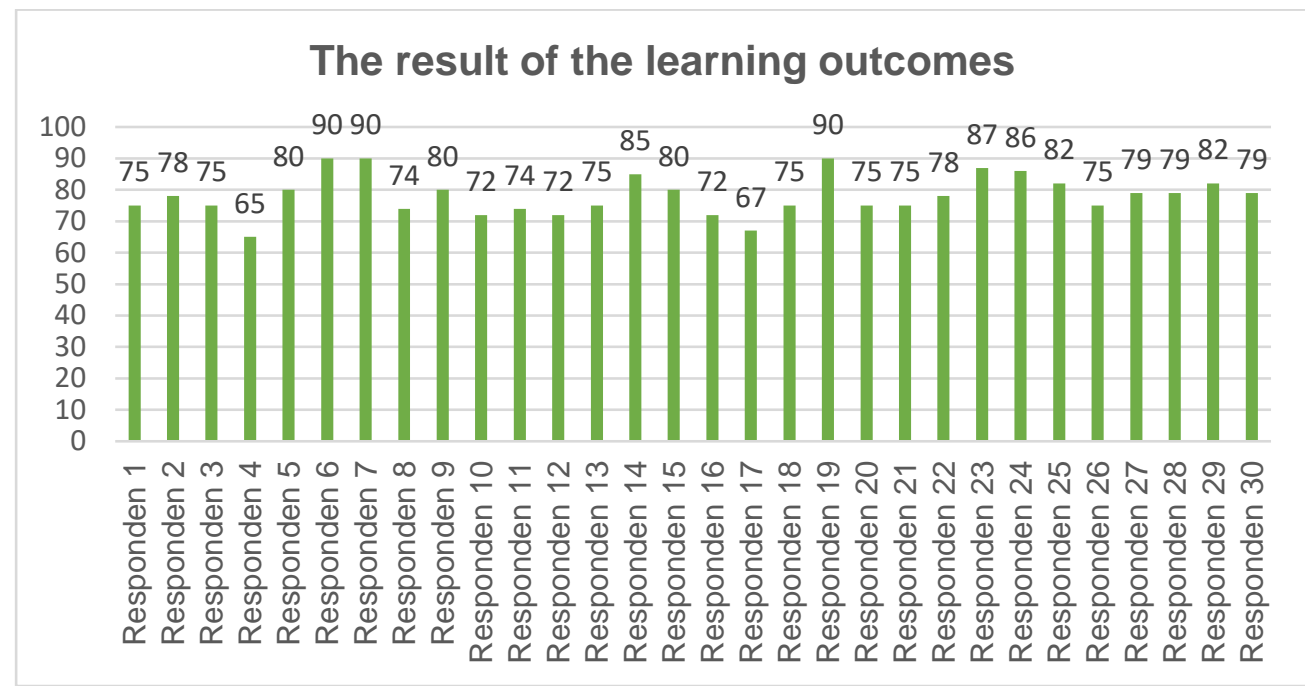

Figure 7. The result of learning outcomes

Figure 7. It shows that the percentage of student learning completeness is $78.20 \%$. This shows the ability of students to solve and pose problems that have developed well according to indicators of predetermined achievement. This result is better than the class that is not taught using them with the percentage of completeness of $56.32 \%$.

b. Students' Response

The student response was the assessment (opinion) of students towards teaching materials oriented to solving and posing problems that had been developed in the development phase and applied in the implementation phase. The Student responses were known from the results of the instrument in the form of a closed questionnaire related to the application of research-based learning. Responses from 30 students obtained through questionnaires were presented in Figure 8.

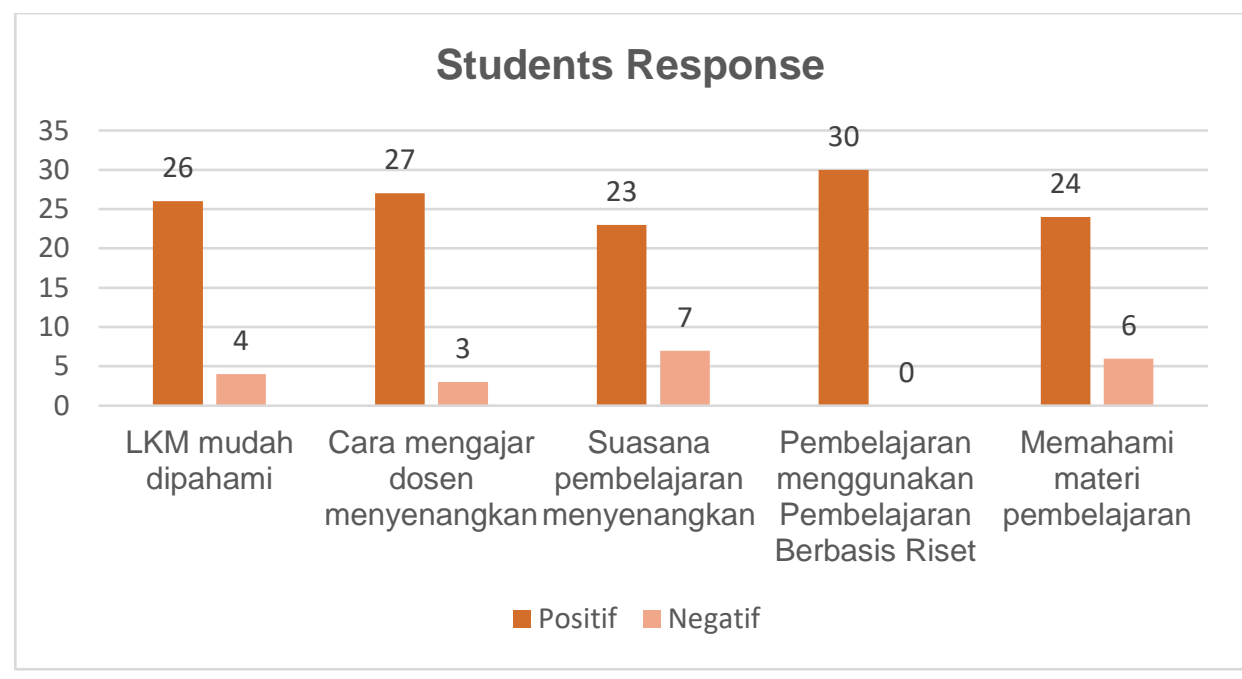

Figure 8. Student Response

Based on Figure 8. the students showed the positive response to the application and development of teaching materials with Solving and posing problems oriented with setting 
BR at the Mathematics Statistics. The positive response of students was more than $75 \%$ for each component and overall the positive response of students was $88.67 \%$.

The results indicate that the research-based learning materials are problem solving and the Posing oriented of mathematical statistical problems had been successfully developed. The application of teaching materials research with solving and the posing problem was effective in mathematical statistical problems. It can be seen from the completeness of student learning outcomes when compared to class learning outcomes that are not taught with it.

The PBR is based on the philosophy of constructivism, namely: (1) building understanding of the students, (2) developing prior knowledge, (3) being the process of social interaction and (4) meaningful learning as always experienced in reality (Widayati et al., 2010). The learning that refers to PBR has been widely developed, one of argument by Slameto, Wardani, \& Kristin (2016), with steps: (1) providing basic information about the material, (2) showing the results of research in contact with lecturers with the material being discussed, (3) dividing students into discussion groups, (4) giving assignments to students in the group discussions, (5) The students conducting group discussions with lecturers, (6) together with student lecturers making conclusions. The assignments in group discussions can be designed in small-scale research activities with interesting issues in accordance with the discussion material. The students discussed in a small way (experiment), analyze the problems and solve the problems. After that the students were asked to form new problems based on the solving process that has been done before. The various research showed that PBR is effectively used to develop processes and improve learning outcomes (Blackmore \& Fraser, 2007; Chrysti S, 2012; Masfingatin, Murtafiah, \& Krisdiana, 2017; Slameto, 2015). PBR was considered to increase academic achievement, promoting the learning process, and encouraging students to build knowledge (Blackmore \& Fraser, 2007). Based on the results of previous research studies it was concluded that scientific learning or based on intelligence is Active Learning, InquiryBased Learning, Problem-Based Learning, and Pioneer Instruction can realize effective learning that is inspiring and able to improve learning outcomes (Slameto, 2015). Likewise the results of previous studies indicate that research-based learning with problem solving methods can develop the professional competencies of mathematics teacher candidates in geometry subjects (Masfingatin, Murtafiah, \& Krisdiana, 2017). In addition, Chrysti (2012) states that research-based learning is effective for developing students' learning processes in Science learning, namely on aspects of communication and collaboration and cognitive abilities, namely problem solving abilities.

This result is also in line with the results of the Suntusia, Dafik, \& Hobri (2019) states that research-based learning is effective to improve students' ability to solve arithmetic sequence problems. Through research-based learning, the students actively participate and are accustomed to high-level thinking in solving and posing problems. Students who apply the scientific approach (research-based learning) have better problem solving skills than students who use other approaches (Yuliati, Riantoni, \& Mufti, 2018). The application of research-based learning conditions students to deal with reading, analyzing, synthesizing, and presenting and discussion that can improve cognitive skills, communication, information technology skills, 
and satisfaction in finding information, all found in students in higher education (Sota \& Karl, 2017). The learning activities are designed to teach students to become researcher, so that it is in accordance with the characteristics of mathematical statistics that require students to conduct investigations because the students are related to problems in everyday life. The same statement was also expressed by Amelia (2018) which states that through research-based learning, the students can build small-scale research activities that become the task undergraduate thesis and teaching with the values of researchers. The research-based learning needs to be developed and applied in various subjects to expand research in studies, apply research in education, and strengthen the relationship between research and teaching (Schapper \& Mayson, 2010).

The research-based learning is demands of learning in higher education, namely the KKNI can be achieved by students well. The students can adapt to the problems at hand; master the theoretical concepts of certain fields of knowledge in general and in depth and formulate procedural problem solving; make decisions quickly based on analysis of information and data and provide guidance in choosing various alternative solutions.

\section{CONCLUSION AND SUGGESTION}

The results of the research show the Development of Research-based learning materials with problem solving and problem posing oriented, (1) the validity of teaching materials consisting of valid Semester Lesson Plans (RPS) both in content and constructs, research-based Student Activity Sheets and Test assessment sheets Learning outcomes with a good and very good assessment of the validator that can be used but with the revision, (2) The positive response of students to teaching materials is $88.67 \%$, (3) The effectiveness of teaching materials is seen based on student learning completeness of 78, 20\%. Thus the Development of Researchbased learning materials with problem solving and problem posing oriented of Statistics Mathematics are appropriate to use in learning Mathematics Statistics.

Based on the results of the research, it is recommended that the lecturers apply The research-Based Learning in teaching so that research skills can improve within the students. The research-based learning process that emphasizes solving and posing problems can be further developed in other subjects in order to develop the students' thinking skills.

\section{REFERENCE}

Abduh, M. (2018). Interaksi Pada Pendekatan Saintifik ( Kajian Teori Scaffolding ). In Seminar Nasional Pendidikan PGSD UMS \& HDPGSDI Wilayah Jawa.

Akay, H., \& Boz, N. (2010). The Effect of Problem Posing Oriented Analyses-II Course on the Attitudes toward Mathematics and Mathematics Self-Efficacy of Elementary Prospective Mathematics Teachers. Australian Journal of Teacher Education, 35(1).

Amelia, T. (2018). The Implementation of Research-based Learning on Biology Seminar Course in Biology Education Study Program of FKIP UMRAH. IOP Conference Series: Materials Science and Engineering, 335(1).

Blackmore, P., \& Fraser, M. (2007). Research Based Learning Strategies for Successfully Linking Teaching and Research. Journal of Education, 13(2), 1-13. 
Chrysti S, K. (2012). Implementasi Pembelajaran Berbasis Riset Kajian: Fermentasi Limbah Cucian Beras (Leri) Untuk Pembuatan Nata Pada Mata Kuliah Konsep Dasar IPA Mahasiswa S1 PGSD FKIP UNS. In Seminar Nasional VIII Pendidikan Biologi (pp. 247252).

Creswell, J. W. (2012). Educational research: Planning, conducting, and evaluating quantitative and qualitative research. Educational Research (Vol. 4).

Febriana, L. C., Sulur, \& Yudyanto. (2014). Pengembangan Lembar Kerja Siswa (LKS) Fisika Materi Tekanan Mencakup Ranah Kognitif, Afektif dan Psikomotor Sesuai Kurikulum 2013 untuk Siswa SMP/MTs. Jurnal Universitas Negeri Malang, 2(1), 1-12.

Fenrich, P. (1997). Practical Guidelines For Creating Instructional Multimedia Applications. Forth Worth: The Dryden Press.

Herwati. (2016). Pengembangan modul keanekaragaman aves sebagai sumber belajar biologi. Jurnal Lentera Pendidikan LPPM UM Metro, 1(1), 28-36.

Kemenristek Dikti. (2016). Panduan Penyusunan Kurikulum Pendidikan Tinggi (2nd ed.). Jakarta: Dirjen Pembelajaran dan Kemahasiswaan Kemenristek Dikti.

Kilic, C. (2013). Turkish Primary School Teachers' Opinions about Problem Posing Applications: Students, the Mathematics Curriculum and Mathematics Textbooks. Australian Journal of Teacher Education, 38(5), 143-155.

Latifah, S. (2015). Pengembangan Modul IPA Terpadu Terintegrasi Ayat-Ayat Al-Qur'an Pada Materi Air Sebagai Sumber Kehidupan. Al-Biruni : Jurnal Ilmiah Pendidikan Fisika, 4(2), $155-164$.

Mardayani, S., Hamdi, \& Murtiani. (2013). Pengembangan Bahan Ajar Fisika Yang Terintegrasi Nilai-Nilai Ayat Al-Quran Pada Materi Gerak Untuk Pembelajaran Siswa Kelas X SMA. Pillar of Physics Education, 1(1), 39-47.

Masfingatin, T., Murtafiah, W., \& Krisdiana, I. (2017). Pembelajaran berbasis riset untuk mengembangkan kompetensi profesional mahasiswa pada mata kuliah geometri. In Prosiding Seminar Hasil Penelitian dan Pengabdian Kepada Masyarakat UNIPMA 2017 (pp. 139-145).

Mulyana, T. (2012). Pengembangan bahan ajar melalui penelitian desain. Infinity, 1(2), 126137.

Nuha, M. 'Azmi, Waluya, S. B., \& Junaedi, I. (2018). Mathematical Creative Process Wallas Model in Students Problem Posing with Lesson Study Approach. International Journal of Instruction, 11(2), 527-538.

Prahmana, R. C. I. (2015). Penelitian Pendidikan Matematika Pembelajaran Berbasis Riset. Yogyakarta: Matematika.

Putra, R. W. Y., \& Anggraini, R. (2016). Pengembangan Bahan Ajar Materi Trigonometri Berbantuan Software iMindMap Pada Siswa SMA. Al-Jabar: Jurnal Pendidikan Matematika, 7(1), 39-47. 
Sari, F. K., Farida, \& Syazali, M. (2016). Pengembangan Media Pembelajaran (Modul) berbantuan Geogebra Pokok Bahasan Turunan. Al-Jabar: Jurnal Pendidikan Matematika, $7(2), 135-151$.

Sari, N., \& Surya, E. (2017). Analysis Effectiveness of Using Problem Posing Model in Mathematical Learning. International Journal of Sciences: Basic and Applied Research (IJSBAR), 33(3), 13-21.

Schapper, J., \& Mayson, S. E. (2010). Research-led Teaching: Moving from a Fractured Engagement to a Marriage of Convenience. Higher Education Research \& Development, $29,641-651$.

Siska, Y. (2015). Analisis Kebutuhan Bahan Ajar Sejarah Lokal Lampung Untuk Sekolah Dasar. Mimbar Sekolah Dasar, 2(2), 199-211.

Siswono. (2008a). Proses Berpikir Kreatif Siswa dalam Memecahkan dan Mengajukan Masalah Matematika. Jurnal Ilmu Pendidikan, 15(1), 60-68.

Siswono, T. Y. E. (2008b). Promoting Creativity In Learning Mathematics Using Open-Ended Problems. In The 3rd International Conference on Mathematics and Statistics (ICoMS-3).

Slameto, S. (2015). Pembelajaran Berbasis Riset Mewujudkan Pembelajaran Yang Inspiratif. Satya Widya, 31(2).

Slameto, S., Wardani, N. S., \& Kristin, F. (2016). Pengembangan Model Pembelajaran Berbasis Riset Aras Tinggi. Prosiding Konser Karya Ilmiah Nasional, 213-227.

Sota, C., \& Karl, P. (2017). The E ffectiveness of Research Based Learning among Master degree Student for Health Promotion and Preventable Disease. Procedia - Social and Behavioral Sciences, 1359-1365.

Sri Anggoro, B. (2015). Pengembangan Modul Matematika Dengan Strategi Problem Solving Untuk Mengukur Tingkat Kemampuan Berfikir Kreatif Matematis Siswa. Al-Jabar, 6(2), 27-39.

Sugiyono. (2015). Metode Penelitian Kombinasi (Mixed Methods). Bandung: Alfabeta.

Suntusia, Dafik, \& Hobri. (2019). The Effectiveness of Research Based Learning in Improving Students ' Achievement in Solving Two-Dimensional Arithmetic Sequence Problems. International Journal of Instruction, 12(1), 17-32.

Susanti, E. L., Sukestiyarno, Y. L., \& Sugiharti, E. (2012). Efektifitas Pembelajaran Matematika dengan Metode Problem Posing Berbasis Pendidikan Karakter. Unnes Journal of Mathematics Education, 1(1), 13-19.

Susialita, T. (2016). The Development Of Audio-Visual Student Portofolio(LKS) Contextual Teaching And Learning-Based (CTL) On Sound Chapter Of Science Suject For Deaf Student. Jurnal Pendidikan IPA Indonesia, 5(2), 192-198.

Wibowo, E., \& Pratiwi, D. D. (2018). Pengembangan Bahan Ajar Menggunakan Aplikasi Kvisoft Flipbook Maker Materi Himpunan. Desimal : Jurnal Matematika, 1(2), 147-156. 
Yuliati, L., Riantoni, C., \& Mufti, N. (2018). Problem Solving Skills on Direct Current Electricity through Inquiry-Based Learning with PhET Simulations. International Journal of Instruction, 11(4), 123-138. 